\title{
Influence of Dry Period Length of Swedish Dairy Cows on the Proteome of Colostrum ${ }^{\dagger}$
}

\author{
Ruben de Vries $^{1,2}{ }^{\text {, Sjef Boeren }}{ }^{3}\left(\mathbb{D}\right.$, Kjell Holtenius $^{1}{ }^{(0}$, Jacques Vervoort ${ }^{3}$, \\ Helena Lindmark-Månsson ${ }^{4}$ and Kasper Hettinga ${ }^{2, *(D)}$ \\ 1 Department of Animal Nutrition and Management, Swedish University of Agricultural Sciences, \\ Box 7024, 75007 Uppsala, Sweden; devries@nzo.nl (R.d.V.); kjell.holtenius@slu.se (K.H.) \\ 2 Dairy Science and Technology, Food Quality and Design, Wageningen University, Box 8129, \\ 6700 EV Wageningen, The Netherlands \\ 3 Laboratory of Biochemistry, Wageningen University, Stippeneng 4, 6708 WE Wageningen, The Netherlands; \\ sjef.boeren@wur.nl (S.B.); jacques.vervoort@wur.nl (J.V.) \\ 4 Dairy Sweden, Ideon Science Park, 22370 Lund, Sweden; helena.lindmark-mansson@lrf.se \\ * Correspondence: kasper.hettinga@wur.nl; Tel.: +31-317-482401 \\ $+\quad$ This paper is a part of the PhD Thesis of Ruben de Vries, present at the Wageningen University \\ (The Netherlands).
}

Received: 4 November 2020; Accepted: 4 December 2020; Published: 11 December 2020

check for updates

\begin{abstract}
The aim of this study was to evaluate the influence of applying a 4-week instead of an 8-week dry period to dairy cows on the proteome of colostrum (first sample) and of transition milk (the fifth postpartum milk sample). Individual milk serum samples of colostrum and transition milk were analysed from 12 Swedish Holstein (SH) and 12 Swedish Red (SR) cows. Samples were prepared by filter-aided sample preparation and dimethyl labelling and analysed by liquid chromatography tandem mass spectrometry. Shortening the dry period resulted in upregulation of 18 proteins in colostrum and transition milk of SR, whereas no statistical differences were found for SH colostrum and transition milk. These upregulated proteins may reflect a specific immune response in the SR samples that was reflected in colostrum as well as in transition milk. Upregulated proteins in colostrum seemed to reflect increased mammary epithelial cell proliferation in the periparturient period when a 4-week dry period was applied. The proteome data indicate that a dry period of 4 weeks to SR cows may not be sufficient for complete regeneration of the mammary epithelium.
\end{abstract}

Keywords: colostrum; transition milk; proteomics; immune proteins; dry period

\section{Introduction}

A dry period of 6-8 weeks is known to maximise the milk yield of dairy cows in their successive lactation [1]. High milk yield generally aggravates a negative energy balance in early lactation. The negative energy balance is related to increased risk of metabolic and reproductive problems. Shortening the dry period is a strategy to ameliorate the negative energy balance in early lactation [2]. A milk yield reduction in early lactation was observed after applying a 28-30 day dry period instead of a 56-60 day dry period [2-4]. The milk yield over the entire lactation was decreased by shortening the dry period according to the study of Watters et al. (2008); however, in other studies, no significant differences were found [5]. Colostrum yield was reduced when a 30 day $(5.3 \mathrm{~kg})$ instead of 60 day $(7.7 \mathrm{~kg})$ dry period was applied [6]. Mastitis incidence was not influenced by shortening the dry period [5,7]. Complete omission of the dry period resulted in a stronger reduction in milk yield [2] and elevated SCC in early lactation [8], compared to a dry period of 30 days. However, most studies on a shortening or omission of the dry period have been performed in Holstein cows, which are known 
for their high milk yield. Whether similar effects can be found in dual-purpose breeds has been much less studied. A recent study comparing the effect of a shorter dry period on Swedish Holstein (SH) to Swedish Red (SR) cows did not show a distinct effect of cow breed on their response [9].

Prepartum renewal of mammary epithelial cells was reported to occur to a high extent in a dry mammary gland [10,11], as compared with a lactating mammary gland [11]. High numbers of renewed secretory epithelial cells at the beginning of lactation were suggested to be responsible for the high milk production of cows with a 60 day dry period [1]. During a 60 day dry period of cows, secretory capacity of the epithelial cells reduced until day 25 in the dry period. In the last 35 days of the dry period, secretory activity of epithelial cells increased to a higher level than was the case for cows that were lactating until parturition [11]. Although direct experimental data are lacking, reduced milk yield and udder size indicate that mammary gland development seems to be diminished in cows with a shortened dry period as compared to a 60 day dry period [12]. Hence, the dry period is an important period for the mammary epithelium to prepare for the successive lactation. However, whether this response differs between breeds, such as $\mathrm{SH}$ and SR, is unknown, although the effect of a shortened dry period on the negative energy balance seems to be more pronounced for cows having a higher milk yield [13].

Colostrum quality is important as colostrum is the first food source for the new-born calf, and it is key in developing its immune system. Colostrum contains both major milk proteins, such as caseins, as well as over 200 other proteins with various functionalities [14,15]. Antimicrobial- and immunity-related proteins were found to be more abundant in colostrum compared to mature milk $[14,15]$. Two days postpartum, the milk proteome showed a transition from colostrum-like towards a proteome comparable with mature milk [15]. Most research related to variation of the milk proteome has focused on changes as a result of pathogen-induced mastitis. Besides proteins with direct antimicrobial activity such as cathelicidins and lactotransferrin (LTF), proteins also related to epithelial barrier integrity such as clusterin (CLU) and plasminogen (PLG) were found to be upregulated in mastitic milk $[16,17]$. Variation in the content of immune proteins that are important for the neonate has mainly be related to mastitis thus far, and to a minor extent to lactation stage, but limited work has been done on the effect of dry period length.

Shortening the dry period to 28 days was reported to not influence protein concentration of colostrum compared with a 56 day dry period [3]. The IgG concentration in colostrum was not affected by shortening the dry period to 30 days either $[4,6,18]$, although IgG yield of cows with a 30 day dry period was lower compared to a 60 day dry period due to a reduced colostrum yield [6]. To our knowledge, no more detailed work on the colostrum proteome in relation to dry period length exists up to date. The aim of this study was thus to evaluate the colostrum and transition milk proteome of cows with a shortened dry period, including both the higher productive $\mathrm{SH}$ and the dual-purpose SR cow breed. Outcomes can be used to generate a better understanding of processes in the mammary gland in the periparturient period.

\section{Materials and Methods}

\subsection{Experimental Design, Animals, Sampling}

The Uppsala Local Ethics Committee approved the experimental protocol (C178/12). For the current study, $12 \mathrm{SH}$ and $12 \mathrm{SR}$ cows in late lactation with proper udder health were used. Of the SH cows, 6 were 2nd parity, 3 were 3rd parity, and 3 were 4th parity. Of the SR cows, 7 were 2nd parity, 4 were 3 rd parity, and 1 was 5 th parity. Cows were blocked according to parity and dried off either 4 or 8 week before expected parturition. The cows were housed at the Swedish Livestock Research Centre Lövsta in a loose house system with slatted floor and cubicles with rubber mats and shopped straw as bedding. Water was always available ad libitum. About a week before expected calving, the cows were moved to individual calving boxes with shopped straw as bedding. No intramammary antibiotics were used at drying off. Before dry-off, the cows were fed silage ad libitum and concentrate 
according to milk production. The week prior to dry-off, concentrate was withdrawn, and during the dry off procedure, the cows were fed $4 \mathrm{~kg}$ DM of silage and straw ad libitum and no concentrate. After dry-off, the cows were fed a blend of silage and straw ad libitum, and concentrate was stepwise increased to $3 \mathrm{~kg}$ at parturition. Milk samples were taken at the first (colostrum) and the fifth milking (transition milk) after calving, while the cows were still kept in the calving boxes and milked in buckets. Samples were taken as aliquots of the entire milking, resulting in a total of 24 samples per breed. The milk yield was recorded at the sampling day. Samples were preserved with $0.03 \%$ Bronopol and stored at $-20^{\circ} \mathrm{C}$ immediately after collecting. Analysis of protein, fat, lactose, and somatic cell counts were done in house, using an infrared spectroscopy method (FTIR, Fourier Transform Instrument, FT 120, Foss Electric, Hillerød, Denmark). Colostrum samples were diluted 3 times with ultrapure water prior to FTIR analysis. All 48 individual samples were used for analysis of their protein composition by liquid chromatography tandem mass spectrometry (LC-MS/MS).

\subsection{Milk Serum Preparation}

Colostrum samples were diluted 4 times with ultrapure water after thawing. All samples were centrifuged $\left(1500 \times \mathrm{g}, 10 \mathrm{~min}, 10^{\circ} \mathrm{C}\right)$, and the fat layer was removed. Samples were ultracentrifuged $\left(100,000 \times g, 90 \mathrm{~min}, 30^{\circ} \mathrm{C}\right)$ using a Beckman L60 ultracentrifuge equipped with a 70 Ti rotor. A pellet of caseins and a transparent milk serum fraction were formed. Milk serum was collected and stored at $-20^{\circ} \mathrm{C}$ prior to further analyses. Protein concentration of serum samples was determined by BCA assay [15]. Serum samples were diluted to a protein concentration of $10 \mu \mathrm{g} / \mu \mathrm{L}$ using ultrapure water. One pooled serum sample was made for SH and 1 for SR, consisting of equal volumes of diluted milk serum of all 24 samples of either SH or SR colostrum and milk.

\subsection{Sample Preparation for LC-MS/MS Analysis}

Filter-aided sample preparation (FASP) was done according to [19] and was followed by dimethyl labelling. Dimethyl labelling is a method that was proved for accurate milk protein quantification $[19,20]$. Dimethyl labelling was done according to [20], using C18+ stage tips that were prepared in house according to [19]. Tryptic digests of individual colostrum and milk serum samples were labelled with a heavy label (cyanoborohydride with deuterated formaldehyde). Tryptic digests of pooled colostrum and milk serum samples were labelled with a light label (cyanoborohydride with normal formaldehyde).

\section{4. $L C-M S / M S$}

If not mentioned differently, the technical details are identical to Zhang et al. [15]. Trypsin-digested and dimethyl-labelled colostrum and milk serum fractions were loaded $(18 \mu \mathrm{L})$ on a $0.10 \times 30 \mathrm{~mm}$ Magic C18AQ 200A $5 \mu \mathrm{m}$ beads (Michrom Bioresources Inc., Auburn, CA, USA) pre-concentration column (prepared in house). The maximum column pressure was 270 bar. Pre-concentration was followed by elution onto a $0.10 \times 200 \mathrm{~mm}$ Magic C18AQ 200A $3 \mu \mathrm{m}$ beads analytical column (Michrom Bioresources Inc., USA). A gradient from 8 to $33 \%$ of acetonitrile in water with $0.5 \%$ acetic acid was applied at a flow rate of $0.5 \mathrm{~mL} / \mathrm{min}$ for $50 \mathrm{~min}$. Post-run column washing was done by increasing the percentage acetonitrile to $80 \%$ (with $20 \%$ water and $0.5 \%$ acetic acid in the acetonitrile and the water) in $3 \mathrm{~min}$. The pre-concentration and the analytical column were connected by a P777 Upchurch micro-cross. A stainless-steel needle that fitted into the waste line of the micro-cross was used for applying a direct electrospray potential of $3.5 \mathrm{kV}$ to the eluent. Full scan FTMS spectra in LTQ-Orbitrap XL (Thermo electron, San Jose, CA, USA) were measured in positive mode between an $\mathrm{m} / z$ of 380 and 1400. Of the four most abundant multiply charged peaks in the FTMS scan, CID fragmented MS/MS scans were recorded in a data-dependent mode in the linear trap (MS/MS threshold $=5000)$. 


\subsection{Protein Identification and Quantification}

Maxquant 1.3.0.5 with Andromeda search engine [21] was used for analysing all MS/MS spectra from each run. Carbamidomethylation of cysteines was set as a fixed modification (enzyme $=$ trypsin, maximally 2 missed cleavages, peptide tolerance $20 \mathrm{ppm}$, fragment ions tolerance $0.5 \mathrm{amu}$ ). Oxidation of methionine, $\mathrm{N}$-terminal acetylation, and deamidation of asparagine or glutamine were set as variable modification for both identification and quantification. The bovine reference database for peptide and protein searches was downloaded as fasta files from Uniprot [22] with reverse sequences generated by Maxquant. Sequences of 31 common contaminant proteins were added including Trypsin (P00760, bovine), Trypsin (P00761, porcine), Keratin K22E (P35908, human), Keratin K1C9 (P35527, human), Keratin K2C1 (P04264, human), and Keratin K1C1 (P35527, human). A maximum of 2 missed cleavages were allowed, and mass deviation of 0.5 Da was set as a limitation for MS/MS peaks and maximally $6 \mathrm{ppm}$ deviation on the peptide $\mathrm{m} / \mathrm{z}$ during the main search. The false discovery rate (FDR) was set to $1 \%$ on both peptide and protein level. The length of peptides was set to at least 7 amino acids. Finally, proteins were displayed based on minimally 2 distinct peptides of which at least 1 was unique.

\subsection{Statistical Analyses}

Protein concentrations were corrected for dilution factors, since all milk serum samples were diluted to a protein concentration of $10 \mu \mathrm{g} / \mu \mathrm{L}$. Differences in protein concentrations between cows with a 4 or an 8 week dry period were based on dimethyl ratios between individual samples and the pooled sample. Dry period comparison was done with a two-sample $t$-test in Perseus 1.3.0.4 [23]. A permutation-based false discovery rate of 0.05 was applied to correct for multiple testing. As there was 1 pooled sample for $\mathrm{SH}$ and 1 for SR, statistical analysis was done separately per breed. Proteins quantified in less than half of the samples were excluded from statistical analyses. Differences in milk yield, macronutrient composition, and SCC between cows with either a 4 or an 8 week dry period were tested using an independent samples $t$-test in SPSS 22 (IBM SPSS Statistics, Armonk, NY, USA). This $t$-test was done within breeds (SH or SR) and sampling moments (colostrum or transition milk).

\section{Results}

\subsection{Colostrum and Milk Composition}

Five colostrum samples had SCC $>10^{7}$ cells $/ \mathrm{mL}$, whereas the average SCC of the other samples was $2.5 \times 10^{6}$ cells $/ \mathrm{mL}$. The underlying cause of the high SCC is not clear, but it was not dry-period-related, as these five samples were distributed over all groups: two SR 4 week dry period, one SR 8 week dry period, one SH 4 week dry period, one SH 8 week dry period. These samples had clearly distinct proteomes, although the limited sample number per breed (2 or 3) was not appropriate for further analysis. If not mentioned differently, comparisons between dry periods is done after exclusion of cows that had SCC $>10^{7}$ cells $/ \mathrm{mL}$ in colostrum. Both colostrum and transition milk samples of these cows were left out. Although these high SCC samples were included in the pooled samples used as a reference for the dimethyl labelling-based quantification, these samples do not present a problem, as a structural change in the reference sample will not influence the comparison between individual samples. Colostrum yields did not differ between cows with a 4 and an 8 week dry period (Table 1). Colostrum protein percentage of SH with a 4 week dry period (15.5\%) was higher than with an 8 week dry period $(11.7 \%)$. Lactose content in colostrum of SH with a 4 week dry period (5.2\%) was lower compared with SH with an 8 week dry period (5.5\%). SCC in colostrum of SH with a 4 week dry period $\left(5.0 \times 10^{6}\right.$ cells $\left./ \mathrm{mL}\right)$ was higher compared with SH with an 8 week dry period $\left(1.4 \times 10^{6}\right.$ cells $\left./ \mathrm{mL}\right)$. Colostrum composition of SR did not differ between cows with either a 4 or an 8 week dry period (Table 1). 
Table 1. Yield, macronutrient composition, somatic cell count (SCC), and number of quantified proteins in colostrum and transition milk of individual Swedish Holstein and Swedish Red cows with either a 4 or an 8 week dry period. Differences between dry period lengths, within breeds, and sampling moment (colostrum or transition milk) are tested by an independent samples $t$-test. Values are presented as means with SEM.

\begin{tabular}{|c|c|c|c|c|c|c|c|}
\hline & & \multicolumn{2}{|c|}{ Swedish Red } & \multicolumn{4}{|c|}{ Swedish Holstein } \\
\hline & & $\begin{array}{c}4 \text { Week Dry } \\
N=4\end{array}$ & $\begin{array}{c}8 \text { Week Dry } \\
N=5\end{array}$ & SEM & $\begin{array}{c}4 \text { Week Dry } \\
N=5\end{array}$ & $\begin{array}{c}8 \text { Week Dry } \\
N=5\end{array}$ & SEM \\
\hline \multirow{6}{*}{ Colostrum } & Yield (kg/d) & 5.5 & 10.0 & 2.0 & 6.2 & 7.2 & 1.0 \\
\hline & Fat $(\%)$ & 5.5 & 5.8 & 1.1 & 5.9 & 10.7 & 2.3 \\
\hline & Protein $(\%)$ & 15.1 & 12.6 & 1.4 & $15.5 *$ & 11.7 & 1.0 \\
\hline & Lactose $(\%)$ & 5.3 & 5.3 & 0.2 & $5.2 *$ & 5.5 & 0.1 \\
\hline & $\mathrm{SCC}\left(\times 10^{3} \text { cells } / \mathrm{mL}\right)^{1}$ & 1838 & 1702 & 1020 & $4996 *$ & 1398 & 1221 \\
\hline & Proteins quantified & 107 & 124 & 8.3 & 133 & 119 & 6.2 \\
\hline \multirow[t]{6}{*}{ Transition milk } & Yield $(\mathrm{kg} / \mathrm{d})$ & 15.9 & 23.8 & 3.0 & 26.5 & 28.5 & 4.1 \\
\hline & Fat $(\%)$ & 5.4 & 4.0 & 1.2 & 3.0 & 3.0 & 0.5 \\
\hline & Protein $(\%)$ & 5.8 & 5.6 & 0.2 & 5.4 & 5.1 & 0.2 \\
\hline & Lactose (\%) & 6.4 & 6.5 & 0.1 & 6.7 & 6.6 & 0.1 \\
\hline & $\mathrm{SCC}\left(\times 10^{3} \text { cells } / \mathrm{mL}\right)^{1}$ & 1292 & 510 & 755 & 2524 & 997 & 1529 \\
\hline & Proteins quantified & 127 & 123 & 3.9 & $143 *$ & 124 & 6.2 \\
\hline
\end{tabular}

* Value is significantly higher at $p<0.05$ within a breed and sampling moment (colostrum or transition milk).

${ }^{1} t$-test based on log-values.

\subsection{Proteome of Cows with a 4 or an 8 Week Dry Period}

In total, 222 proteins were quantified based on their dimethyl ratios in the current sample set. The number of quantified proteins was higher in transition milk of SH cows with a 4 week dry period than with an 8 week dry period (Table 1 and Table S1). Concentrations of 18 proteins were higher $(\mathrm{FDR} \leq 0.05)$ in the colostrum of cows with a 4 week dry period compared with an 8 week dry period (Table 2). Upregulated proteins in SR colostrum of 4 week dry cows were 3-58 times more abundant compared with colostrum of 8 week dry cows (Table 2). Differences in protein concentrations are visualized in Figure 1.

Colostrum proteomes of $\mathrm{SH}$ cows showed numerical differences in the same proteins between cows with either a 4 or an 8 week dry period (Figure 2). Quantitatively, however, the fold changes between dry period groups were lower than for SR (Table 2). Hence, no significant changes were found in the colostrum proteome of $\mathrm{SH}$ with either a 4 or an 8 week dry period. Some of the proteins were not quantified for all samples in SH colostrum (Figure 2). However, replacing missing values by a minimum value (the lowest detected concentration of a protein) did also not result in significant differences between cows with a 4 or an 8 week dry period. Colostrum of cows with a 4 week dry period did not have any proteins with lower abundance compared with an 8 week dry period. In transition milk samples of SR, 18 proteins were upregulated (FDR $=0.05)$ in milk of cows that had a 4 week dry period compared with an 8 week dry period. Of these 18 proteins, 10 were upregulated in their respective colostrum samples as well (Table 2, Figure 3). In transition milk of SR, the maximum upregulation was 14-fold (LTF). Like in colostrum, concentrations of individual proteins in transition milk of SH did not differ between cows with either a 4 or an 8 week dry period. 


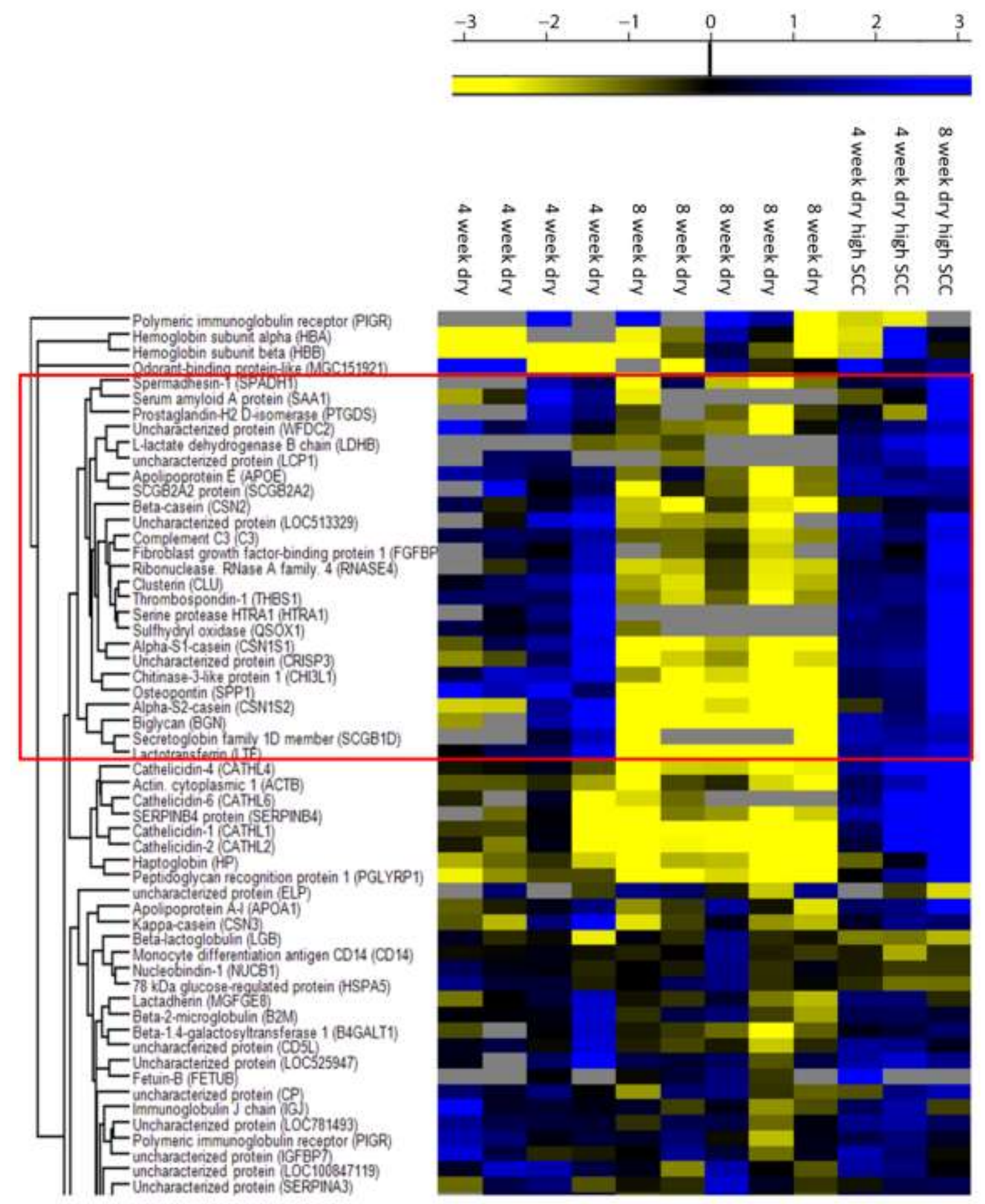

Figure 1. Hierarchically clustered dimethyl ratios of Swedish Red colostrum proteins (rows) shown as a heat map. Columns represent individual samples of cows with a 4 or an 8 week dry period, ordered manually. The 3 far right columns represent colostrum samples with somatic cell count (SCC) $>10^{7}$ cells/mL. Grey cells indicate proteins that were not detected in the specific sample. 


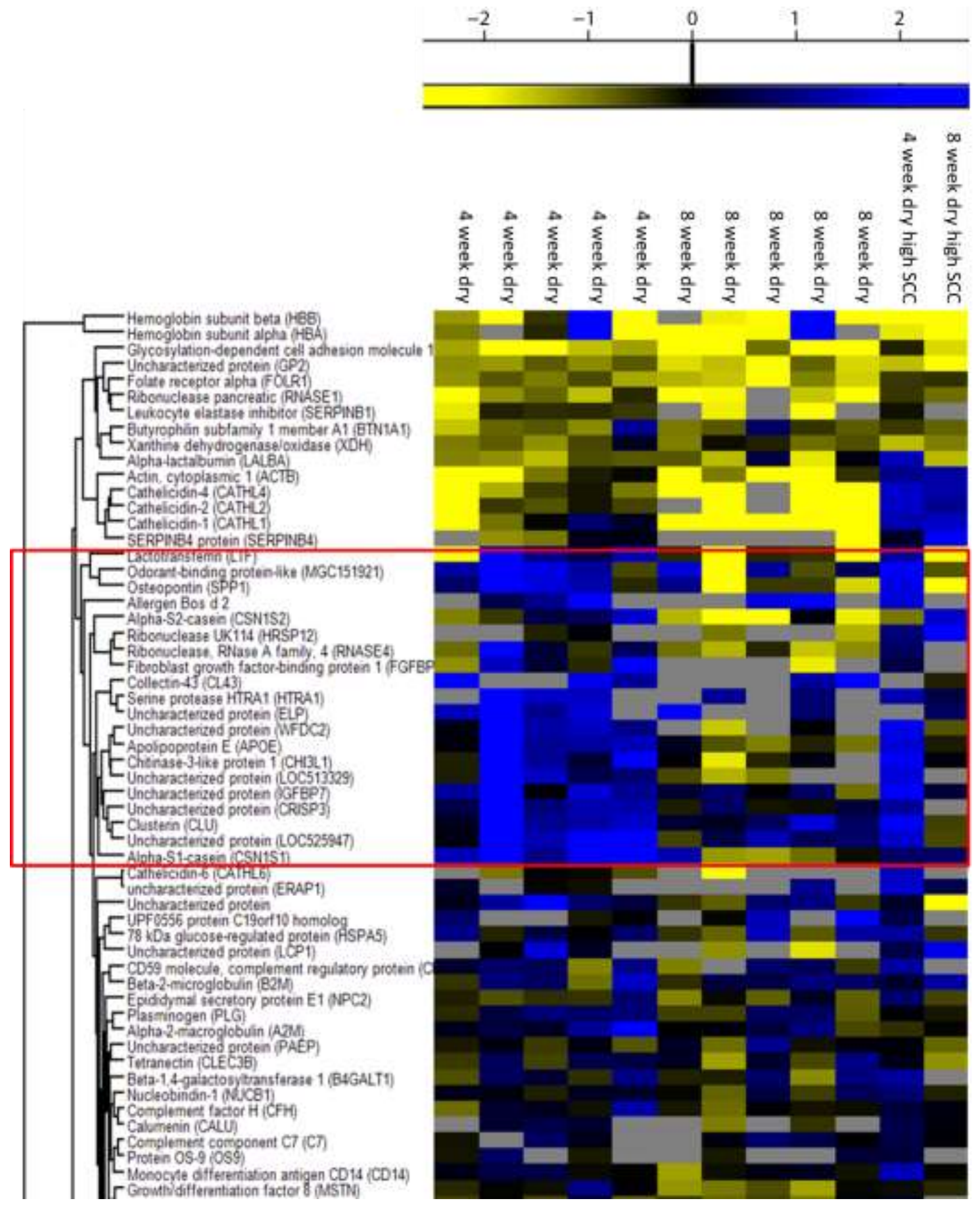

Figure 2. Hierarchically clustered dimethyl ratios of Swedish Holstein colostrum proteins (rows) shown as a heat map. Columns represent individual samples of cows with a 4 or an 8 week dry period, ordered manually. The 2 far right columns represent colostrum samples with SCC $>10^{7}$ cells $/ \mathrm{mL}$. Grey cells indicate proteins that were not detected in the specific sample. 
Table 2. Upregulation factors of proteins in either colostrum or transition milk of Swedish Red (SR) and Swedish Holstein (SH) cows with a 4 week dry period compared with an 8 week dry period. Values represent the protein concentrations in samples of cows with a 4 week dry period relative to the concentrations in samples of cows with an 8 week dry period, based on dimethyl ratios. The proteins that are presented are the proteins that were upregulated (false-discovery rate adjusted $p$-value $=0.05$ ) in colostrum of Swedish Reds with a 4 week dry period compared with an 8 week dry period.

\begin{tabular}{|c|c|c|c|c|c|}
\hline \multirow[b]{2}{*}{ Protein } & \multirow[b]{2}{*}{ Gene } & \multicolumn{2}{|c|}{ Colostrum } & \multicolumn{2}{|c|}{ Transition Milk } \\
\hline & & $\begin{array}{c}\text { SR } \\
(\mathrm{N}=4+5)\end{array}$ & $\begin{array}{c}\mathrm{SH} \\
(\mathrm{N}=5+5)\end{array}$ & $\begin{array}{c}\text { SR } \\
(\mathrm{N}=4+5)\end{array}$ & $\begin{array}{c}\text { SH } \\
(\mathrm{N}=5+5)\end{array}$ \\
\hline \multicolumn{6}{|l|}{ Tissue regeneration } \\
\hline Apolipoprotein E & APOE & $3.4 *$ & 4.0 & 2.9 & 1.7 \\
\hline Biglycan & BGN & $57.7 *$ & ND & 3.5 & ND \\
\hline Thrombospondin-1 & THBS1 & $7.9 *$ & ND & 1.3 & ND \\
\hline Chitinase-3-like protein 1 & CHI3L1 & $17.7 *$ & 6.1 & $3.2 *$ & 0.7 \\
\hline Clusterin & CLU & $8.9 *$ & 2.0 & $6.4^{*}$ & 1.0 \\
\hline \multicolumn{6}{|l|}{ Host-defence } \\
\hline Cathelicidin-2 & CATHL2 & $6.0 *$ & 7.8 & 5.1 & 2.0 \\
\hline Cathelicidin- 4 & CATHL4 & $5.1 *$ & 5.1 & 5.6 & 2.3 \\
\hline Peptidoglycan recognition protein 1 & PGLYRP1 & $3.4 *$ & 1.6 & 3.3 & 4.1 \\
\hline \multicolumn{6}{|l|}{ Mucosal protection } \\
\hline Glycosylation-dependent cell adhesion molecule 1 & GLYCAM1 & $4.0 *$ & 1.3 & $2.0 *$ & 3.1 \\
\hline Lactotransferrin & LTF & $39.1 *$ & 12.9 & $13.5^{*}$ & 2.1 \\
\hline Osteopontin & SPP1 & $33.7 *$ & 9.6 & $4.1^{*}$ & 1.8 \\
\hline \multicolumn{6}{|l|}{ Transport } \\
\hline Alpha-S1-casein & CSN1S1 & $18.5 *$ & 4.8 & $3.8 *$ & 1.2 \\
\hline Beta-casein & CSN2 & $6.2 *$ & 1.4 & $5.2 *$ & 1.1 \\
\hline \multicolumn{6}{|l|}{ Complement system } \\
\hline Complement C3 & $\mathrm{C} 3$ & $4.3 *$ & 1.7 & $2.0 *$ & 1.0 \\
\hline Uncharacterized protein & CFI & $3.4 *$ & 1.6 & $2.0 *$ & 1.1 \\
\hline Uncharacterized protein & LOC513329 & $15.3 *$ & 10.1 & 3.2 & 0.9 \\
\hline
\end{tabular}

* Significantly higher in samples of cows with a 4 week dry period compared with an 8 week dry period (FDR $=0.05)$.

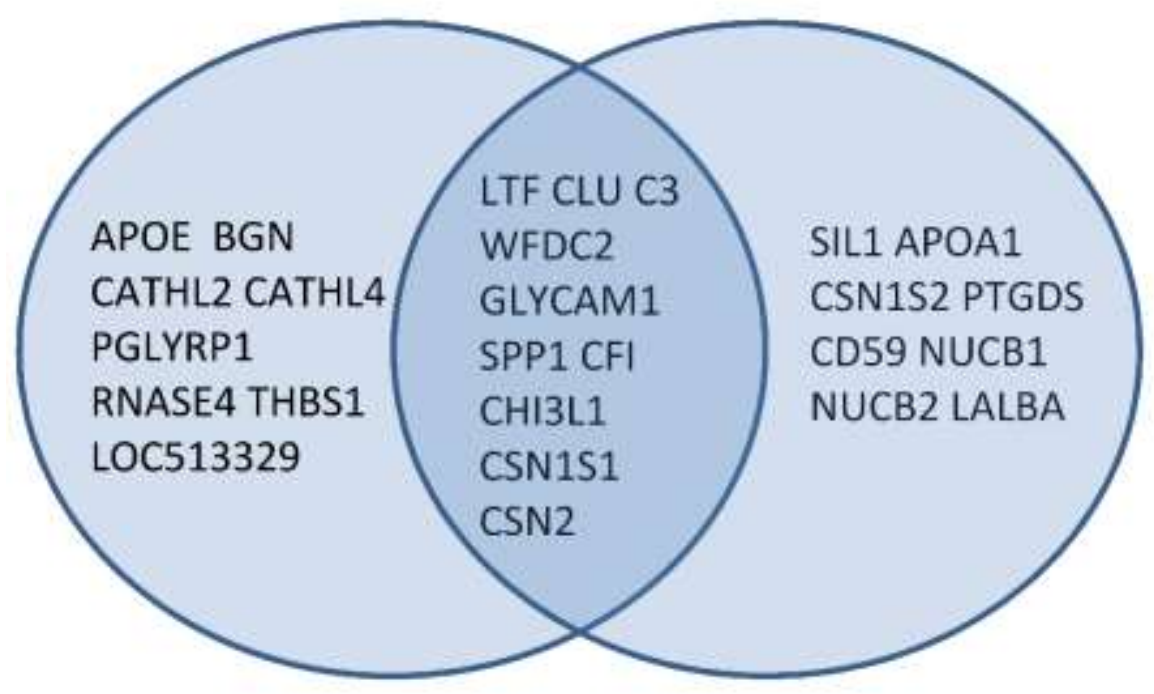

Figure 3. Left circle: proteins upregulated in 9 colostrum samples of Swedish Red cows with a 4 week dry period compared with an 8 week dry period. Right circle: proteins upregulated in transition milk samples of the same cows with a 4 week dry period compared with an 8 week dry period. Proteins in the overlapping of the circles are upregulated in both colostrum and transition milk of cows with a 4 week dry period. 


\section{Discussion}

The current study shows that applying a dry period of 4 week instead of 8 week resulted in an upregulation of 18 proteins in colostrum of SR cows. Of the 18 upregulated proteins, 14 clustered together in a heat map of the quantified SR colostrum proteins (Figure 1, red frame), indicating a similar response for these proteins in colostrum of the individual cows. Of the proteins upregulated in colostrum, 10 were also upregulated in transition milk of these cows (Figure 3). However, no proteins were uniquely upregulated in transition milk, and the level of upregulation was also smaller for transition milk than colostrum (Table 2). For SH colostrum, no differences in individual protein concentrations were found between cows with either a 4 or an 8 week dry period. However, in a heat map of SH colostrum, nine of the proteins that were significantly different in SR colostrum were clustered together (Figure 2, red frame), even though the differences were insignificant for individual proteins for $\mathrm{SH}$. These proteins generally had numerically higher intensities in colostrum of $\mathrm{SH}$ with a 4 week dry period than an 8 week dry period, thus were similar to SR. No difference in the proteome was found in the transition milk samples of SH between cows with a 4 or 8 week dry period. The absence of dry-period-induced proteome differences in transition milk is another indication that the colostrum proteome of SH was affected in a milder way by shortening the dry period than the colostrum proteome of SR (Table 2).

Some of the proteins that were more abundant in colostrum when the dry period was shortened originate from epithelial cells (GLYCAM1, LTF), whereas others may originate both from epithelial as well as somatic cells (cathelicidins, SPP1). Due to practical limitations, samples in this study have been frozen and thawed prior to milk serum preparation, as is commonly done in milk proteomics studies. Previous work has indicated that freeze-thawing of milk has limited or no influence on milk serum concentrations of proteins that are described in the current work [24]. In addition, all samples had undergone the same freeze-thaw cycle. Therefore, freeze-thawing of samples is highly unlikely to have affected the proteome comparison of cows with a 4 or an 8 week dry period. Moreover, there was no difference in SCC between SR with a 4 and an 8 week dry period, and no correlations were found between SCC and proteins such as cathelicidins, after excluding the high SCC cows.

All proteins that were upregulated in colostrum of SR with a 4 week dry period are known to play a role in immune responses, apart from the caseins. In general, the upregulated proteins can be divided into a group of antimicrobial proteins (e.g., cathelicidin-2 and -4 (CATHL2 and CATHL4)), peptidoglycan recognition protein 1 (PGLYRP1 and lactotransferrin (LTF)), and a group of proteins related to tissue regeneration (ao. apolipoprotein E (APOE), biglycan (BGN) and thrombospondin (THBS1)). No acute-phase proteins were upregulated in colostrum of SR cows with a short dry period. This indicates that shortening the dry period induced a preventive rather than an inflammatory nature of the immune response. Such a preventive immune response may be the result of incomplete regeneration of the mammary epithelium. Previous work has shown that a dry period of more than 30 days is needed for complete regeneration of the mammary epithelium of dairy cows [11]. It can be assumed that cows with a 4 week dry period in the current study did not complete an optimal cycle of tissue regeneration of the mammary epithelium. Based on the study of Capuco et al. [11], it is expected that cows with a 4 week dry period still have increased cell regeneration in early lactation. Postpartum changes in protein composition in milk that may reflect mammary epithelial development have not been reported before. The current work indicates that applying a 4 week dry period may result in a preventive immune response postpartum, possibly because of unfinished mammary epithelial cell regeneration.

CATHL2, CATHL4, and PGLYRP1 have direct antimicrobial activity [25] and were more concentrated in colostrum of SR with a 4 week dry period. Cathelicidin gene expression has been found in healthy mammary tissue, indicating that it has a role in tissue maintenance [26]. From these findings, it can be hypothesised that the mammary epithelium of SR cows with a 4 week dry period undergoes more maintenance activity at parturition than that of SR cows with an 8 week dry period. Alpha-caseins have been reported to contain antimicrobial peptides encrypted in their sequence [27], 
though upregulation of caseins in milk serum in relation to mastitis is highly variable over different studies $[17,25,28]$. Casein-derived peptides used for casein identification in the current study comprise a major part of the amino acid sequence, indicating that intact caseins and not their breakdown products were measured. In general, upregulation of antimicrobial proteins in colostrum of cows with a shortened dry period seems to be a result of a tissue-regeneration-related immune response rather than an actual infection.

The high colostrum concentration of LTF, compared with other antimicrobial proteins, indicates that this protein played an important role in the mammary gland of cows with a 4 week dry period. Both in SH and SR, LTF was upregulated proportionally with SPP1, as was observed in previous work [29]. Both LTF and SPP1 have various functionalities. LTF is known as an antimicrobial protein but has also been related to cell proliferation [30] and wound healing due to its immune regulatory properties [31,32]. SPP1 has also been related to immune regulation, wound healing, and mucosal protection [33]. Both the immune as well as cell-regeneration-related functionality of LTF and SPP1 fit in the hypothesis that shortening the dry period of the cow results in an immune response due to altered mammary epithelial tissue. These findings indicate that more tissue regeneration happens after parturition when a shortened dry period is used. The potential involvement of LTF and SPP1 in both immune response and cell regeneration may indicate their key role around parturition in the mammary gland of cows with a shortened dry period, resulting in high concentrations of these proteins in colostrum and transition milk. SPP1 has been described to be involved in protection of the mucosal layer [33], which serves as the first line of defence against bacterial invasion [34]. Glycosylation-dependent cell adhesion molecule 1 (GLYCAM1) is a mucin-like protein that is part of the mucosal layer [35]. Mucin was not detected, since in milk, it is solely present in the milk fat globule membrane and not in milk serum, in contrast to GLYCAM1 [36]. The uncharacterised protein WFDC2 is a protease inhibitor, which in humans has been shown to also protect the mucosal layer [37]. Increased concentrations of GLYCAM1, SPP1, and WFDC2 in colostrum of SR cows with a shortened dry period, indicating increased mucosal protection, seem to confirm an immune response due to altered mammary epithelial tissue. This is in line with the upregulation of antimicrobial proteins described in the previous paragraph. Proteins involved in the protection of the mucosal layer were still upregulated in transition milk (Figure 3). Proteins with direct antimicrobial properties, on the other hand, were not upregulated anymore in transition milk (Figure 3). These results indicate that there may be increased protection of the epithelium when the dry period is shortened, although it seems that there is no persistent antimicrobial immune response.

SR cows with a 4 week dry period had higher colostrum concentrations of APOE, BGN, and THBS1 (Table 2). These proteins have been described to be involved in cell regeneration. APOE has been related to accelerated epithelial injury repair and muscle cell regeneration in mice $[38,39]$. BGN, of which the concentration in colostrum is strongly affected by dry period reduction, has been suggested to be involved in cell growth and differentiation [40]. THBS1 had been related to accelerated re-epithelialisation in wounded corneal epithelia [41]. Mammary involution has been described to be similar to a wound-healing process [42]. Upregulation of APOE, BGN, and THBS1, but also previously discussed LTF and SPP1, in colostrum indicate that a more active wound-healing-like process is going on in the mammary gland around parturition when a 4 week dry period is applied compared with an 8 week dry period. Wound healing related proteins were not upregulated anymore in transition milk of cows with a shortened dry period. In transition milk, predominantly epithelial cell renewal and protection related proteins were upregulated. A comparable phenomenon was found for cows with a 0 day dry period, which had an increased cell proliferation index compared with cows that had a 60 day dry period at the second day postpartum [43]. The current study indicated a more pronounced proteome effect of shortening the dry period for SR than for SH. In previous work, it was indicated that Holstein or Jersey cows had differences in their milk proteome [44,45]. No detailed reports on the milk proteome of SR, or on the proteomic response of different breeds towards intervening in the lactation cycle were found. However, following the hypothesis of increased tissue regeneration of 
cows with a 4 week dry period, it can be suggested that a dual purpose breed (SR) requires more time to regenerate its mammary epithelium between lactations than a pure milk breed (SH).

\section{Conclusions}

In conclusion, results from this proteomics study seem to be in agreement with previous findings that a dry period of 4 week is not sufficient for complete regeneration of the mammary epithelium of cows. Compared with SR, SH cows showed a milder response towards shortening the dry period in colostrum and no response in transition milk, leading to the hypothesis that this breed needs less time for mammary epithelial cell regeneration during the dry period.

Supplementary Materials: The following are available online at http://www.mdpi.com/2624-862X/1/3/21/s1, Table S1: raw proteomics data.

Author Contributions: Conceptualization, R.d.V., K.H. (Kjell Holtenius), H.L.-M. and K.H. (Kasper Hettinga); methodology and formal analysis, S.B., J.V. and K.H. (Kasper Hettinga); data curation, R.d.V., S.B., J.V. and K.H. (Kasper Hettinga); validation, S.B.; visualisation, R.d.V. and K.H. (Kasper Hettinga); writing-original draft preparation, R.d.V. and K.H. (Kasper Hettinga); writing—review and editing, R.d.V., S.B., K.H. (Kjell Holtenius), J.V., H.L.-M. and K.H. (Kasper Hettinga); supervision K.H. (Kjell Holtenius) and K.H. (Kasper Hettinga); project administration, K.H. (Kjell Holtenius); funding acquisition, K.H. (Kjell Holtenius), H.L.-M. and K.H. (Kasper Hettinga). All authors have read and agreed to the published version of the manuscript.

Funding: This research was funded by the Swedish Farmer's Foundation for Agricultural Research (SLF).

Acknowledgments: The authors would like to thank Ariëtte van Knegsel and Toon van Hooijdonk for their input in discussions during the study.

Conflicts of Interest: The authors declare no conflict of interest. The funding sponsor had no role in the design of the study; in the collection, analyses, or interpretation of data; in the writing of the manuscript, and in the decision to publish the results.

\section{References}

1. Kuhn, M.T.; Hutchison, J.L.; Norman, H.D. Minimum days dry to maximize milk yield in subsequent lactation. Anim. Res. 2005, 54, 351-367. [CrossRef]

2. van Knegsel, A.T.M.; Remmelink, G.J.; Jorjong, S.; Fievez, V.; Kemp, B. Effect of dry period length and dietary energy source on energy balance, milk yield, and milk composition of dairy cows. J. Dairy Sci. 2014, 97, 1499-1512. [CrossRef] [PubMed]

3. Rastani, R.R.; Grummer, R.R.; Bertics, S.J.; Gumen, A.; Wiltbank, M.C.; Mashek, D.G.; Schwab, M.C. Reducing dry period length to simplify feeding transition cows: Milk production, energy balance, and metabolic profiles. J. Dairy Sci. 2005, 88, 1004-1014. [CrossRef]

4. Annen, E.L.; Collier, R.J.; McGuire, M.A.; Vicini, J.L.; Ballam, J.M.; Lormore, M.J. Effect of Modified Dry Period Lengths and Bovine Somatotropin on Yield and Composition of Milk from Dairy Cows. J. Dairy Sci. 2004, 87, 3746-3761. [CrossRef]

5. Church, G.T.; Fox, L.K.; Gaskins, C.T.; Hancock, D.D.; Gay, J.M. The Effect of a Shortened Dry Period on Intramammary Infections During the Subsequent Lactation. J. Dairy Sci. 2008, 91, 4219-4225. [CrossRef] [PubMed]

6. Mayasari, N.; Reilingh, G.D.; Nieuwland, M.G.B.; Remmelink, G.J.; Parmentier, H.K.; Kemp, B.; van Knegsel, A.T.M. Effect of maternal dry period length on colostrum immunoglobulin content and on natural and specific antibody titers in calves. J. Dairy Sci. 2015, 98, 3969-3979. [CrossRef]

7. Watters, R.D.; Wiltbank, M.C.; Guenther, J.N.; Brickner, A.E.; Rastani, R.R.; Fricke, P.M.; Grummer, R.R. Effect of dry period length on reproduction during the subsequent lactation. J. Dairy Sci. 2009, 92, 3081-3090. [CrossRef]

8. de Vries, R.; van Knegsel, A.; Johansson, M.; Lindmark-Månsson, H.; van Hooijdonk, T.; Holtenius, K.; Hettinga, K. Effect of shortening or omitting the dry period of Holstein-Friesian cows on casein composition of milk. J. Dairy Sci. 2015, 98, 8678-8687. [CrossRef]

9. Andrée O’Hara, E.; Omazic, A.; Olsson, I.; Båge, R.; Emanuelson, U.; Holtenius, K. Effects of dry period length on milk production and energy balance in two cow breeds. Animal 2018, 12, 508-514. [CrossRef] 
10. Norgaard, J.V.; Theil, P.K.; Sorensen, M.T.; Sejrsen, K. Cellular mechanisms in regulating mammary cell turnover during lactation and dry period in dairy cows. J. Dairy Sci. 2008, 91, 2319-2327. [CrossRef]

11. Capuco, A.V.; Akers, R.M.; Smith, J.J. Mammary Growth in Holstein Cows During the Dry Period: Quantification of Nucleic Acids and Histology. J. Dairy Sci. 1997, 80, 477-487. [CrossRef]

12. Pezeshki, A.; Capuco, A.V.; DeSpiegeleer, B.; Peelman, L.; Stevens, M.; Collier, R.J.; Burvenich, C. An integrated view on how the management of the dry period length of lactating cows could affect mammary biology and defence. J. Anim. Physiol. Anim. Nutr. 2010, 94, e7-e30. [CrossRef] [PubMed]

13. Kok, A.; Chen, J.; Kemp, B.; Van Knegsel, A.T.M. Review: Dry period length in dairy cows and consequences for metabolism and welfare and customised management strategies. Animal 2019, 13, S42-S51. [CrossRef] [PubMed]

14. Le, A.; Barton, L.D.; Sanders, J.T.; Zhang, Q.A. Exploration of Bovine Milk Proteome in Colostral and Mature Whey Using an Ion-Exchange Approach. J. Proteome Res. 2011, 10, 692-704. [CrossRef] [PubMed]

15. Zhang, L.; Boeren, S.; Hageman, J.A.; Van Hooijdonk, T.; Vervoort, J.; Hettinga, K. Bovine milk proteome in the first 9 days: Protein interactions in maturation of the immune and digestive system of the newborn. PLoS ONE 2015, 10, e0116710. [CrossRef] [PubMed]

16. Ibeagha-Awemu, E.M.; Ibeagha, A.E.; Messier, S.; Zhao, X. Proteomics, Genomics, and Pathway Analyses of Escherichia coli and Staphylococcus aureus Infected Milk Whey Reveal Molecular Pathways and Networks Involved in Mastitis. J. Proteome Res. 2010, 9, 4604-4619. [CrossRef]

17. Danielsen, M.; Codrea, M.C.; Ingvartsen, K.L.; Friggens, N.C.; Bendixen, E.; Røntved, C.M. Quantitative milk proteomics-Host responses to lipopolysaccharide-mediated inflammation of bovine mammary gland. Proteomics 2010, 10, 2240-2249. [CrossRef]

18. Watters, R.D.; Guenther, J.N.; Brickner, A.E.; Rastani, R.R.; Crump, P.M.; Clark, P.W.; Grummer, R.R. Effects of Dry Period Length on Milk Production and Health of Dairy Cattle. J. Dairy Sci. 2008, 91, 2595-2603. [CrossRef]

19. Lu, J.; Boeren, S.; de Vries, S.C.; van Valenberg, H.J.F.; Vervoort, J.; Hettinga, K. Filter-aided sample preparation with dimethyl labeling to identify and quantify milk fat globule membrane proteins. J. Proteom. 2011, 75, 34-43. [CrossRef]

20. Boersema, P.J.; Raijmakers, R.; Lemeer, S.; Mohammed, S.; Heck, A.J.R. Multiplex peptide stable isotope dimethyl labeling for quantitative proteomics. Nat. Protoc. 2009, 4, 484-494. [CrossRef]

21. Cox, J.; Mann, M. MaxQuant enables high peptide identification rates, individualized p.p.b.-range mass accuracies and proteome-wide protein quantification. Nat. Biotechnol. 2008, 26, 1367-1372. [CrossRef] [PubMed]

22. UniProt. Available online: https://www.uniprot.org/ (accessed on 1 March 2014).

23. Tyanova, S.; Temu, T.; Sinitcyn, P.; Carlson, A.; Hein, M.Y.; Geiger, T.; Mann, M.; Cox, J. The Perseus computational platform for comprehensive analysis of (prote)omics data. Nat. Methods 2016, 13, 731-740. [CrossRef] [PubMed]

24. Zhang, L.; Boeren, S.; Smits, M.; van Hooijdonk, T.; Vervoort, J.; Hettinga, K. Proteomic study on the stability of proteins in bovine, camel, and caprine milk sera after processing. Food Res. Int. 2016, 82, 104-111. [CrossRef]

25. Alonso-Fauste, I.; Andrés, M.; Iturralde, M.; Lampreave, F.; Gallart, J.; Álava, M.A. Proteomic characterization by 2-DE in bovine serum and whey from healthy and mastitis affected farm animals. J. Proteom. 2012, 75, 3015-3030. [CrossRef] [PubMed]

26. Kosciuczuk, E.M.; Lisowski, P.; Jarczak, J.; Krzyzewski, J.; Zwierzchowski, L.; Bagnicka, E. Expression patterns of beta-defensin and cathelicidin genes in parenchyma of bovine mammary gland infected with coagulase-positive or coagulase-negative Staphylococci. BMC Vet. Res. 2014, 10, 14. [CrossRef] [PubMed]

27. McCann, K.B.; Shiell, B.J.; Michalski, W.P.; Lee, A.; Wan, J.; Roginski, H.; Coventry, M.J. Isolation and characterisation of a novel antibacterial peptide from bovine alpha(s1)-casein. Int. Dairy J. 2006, 16, 316-323. [CrossRef]

28. Smolenski, G.; Broadhurst, M.; Stelwagen, K.; Haigh, B.; Wheeler, T. Host defence related responses in bovine milk during an experimentally induced Streptococcus uberis infection. Proteome Sci. 2014, 12, 1-14. [CrossRef] [PubMed] 
29. Zhang, L.; Boeren, S.; Hageman, J.A.; van Hooijdonk, T.; Vervoort, J.; Hettinga, K. Perspective on calf and mammary gland development through changes in the bovine milk proteome over a complete lactation. J. Dairy Sci. 2015, 98, 5362-5373. [CrossRef]

30. Nakajima, K.; Itoh, F.; Nakamura, M.; Kawamura, A.; Yamazaki, T.; Kozakai, T.; Takusari, N.; Ishisaki, A. Short communication: Opposing effects of lactoferrin on the proliferation of fibroblasts and epithelial cells from bovine mammary gland. J. Dairy Sci. 2015, 98, 1069-1077. [CrossRef]

31. 3Tang, L.; Wu, J.J.; Ma, Q.; Cui, T.; Andreopoulos, F.M.; Gil, J.; Valdes, J.; Davis, S.C.; Li, J. Human lactoferrin stimulates skin keratinocyte function and wound re-epithelialization. Br. J. Dermatol. 2010, 163, $38-47$. [CrossRef]

32. Engelmayer, J.; Blezinger, P.; Varadhachary, A. Talactoferrin stimulates wound healing with modulation of inflammation. J. Surg. Res. 2008, 149, 278-286. [CrossRef] [PubMed]

33. Sodek, J.; da Silva, A.P.B.; Zohar, R. Osteopontin and mucosal protection. J. Dent. Res. 2006, 85, 404-415. [CrossRef] [PubMed]

34. Sando, L.; Pearson, R.; Gray, C.; Parker, P.; Hawken, R.; Thomson, P.C.; Meadows, J.R.S.; Kongsuwan, K.; Smith, S.; Tellam, R.L. Bovine Muc1 is a highly polymorphic gene encoding an extensively glycosylated mucin that binds bacteria. J. Dairy Sci. 2009, 92, 5276-5291. [CrossRef] [PubMed]

35. Dowbenko, D.; Kikuta, A.; Fennie, C.; Gillett, N.; Lasky, L.A. Glycosylation-dependent cell-adhesion molecule-1 (GLYCAM-1) mucin is expressed by lactating mammary-gland epithelial-cells and is present in milk. J. Clin. Investig. 1993, 92, 952-960. [CrossRef]

36. Hettinga, K.; van Valenberg, H.; de Vries, S.; Boeren, S.; van Hooijdonk, T.; van Arendonk, J.; Vervoort, J. The host defense proteome of human and bovine milk. PLoS ONE 2011, 6, e19433. [CrossRef] [PubMed]

37. Tomazic, P.V.; Birner-Gruenberger, R.; Leitner, A.; Obrist, B.; Spoerk, S.; Lang-Loidolt, D. Nasal mucus proteomic changes reflect altered immune responses and epithelial permeability in patients with allergic rhinitis. J. Allergy Clin. Immunol. 2014, 133, 741-750. [CrossRef] [PubMed]

38. Nathan, B.P.; Gairhe, S.; Nwosu, I.; Clark, S.; Struble, R.G. Reconstitution of the olfactory epithelium following injury in ApoE-deficient mice. Exp. Neurol. 2010, 226, 40-46. [CrossRef]

39. Arnold, L.; Perrin, H.; de Chanville, C.B.; Saclier, M.; Hermand, P.; Poupel, L.; Guyon, E.; Licata, F.; Carpentier, W.; Vilar, J.; et al. CX3CR1 deficiency promotes muscle repair and regeneration by enhancing macrophage ApoE production. Nat. Commun. 2015, 6, 8972. [CrossRef]

40. Couchman, J.R.; Woods, A. Structure and Biology of Pericellular Proteoglycans; Roberts, D.D., Mecham, R.P., Eds.; Academic Press Inc.: San Diego, CA, USA, 1993.

41. Uno, K.; Hayashi, H.; Kuroki, M.; Uchida, H.; Yamauchi, Y.; Kuroki, M.; Oshima, K. Thrombospondin-1 accelerates wound healing of corneal epithelia. Biochem. Biophys. Res. Commun. 2004, 315, 928-934. [CrossRef]

42. 4Stein, T.; Salomonis, N.; Gusterson, B.A. Mammary gland involution as a multi-step process. J. Mammary Gland Biol. Neoplasia 2007, 12, 25-35. [CrossRef]

43. Annen, E.L.; Stiening, C.M.; Crooker, B.A.; Fitzgerald, A.C.; Collier, R.J. Effect of continuous milking and prostaglandin E-2 on milk production and mammary epithelial cell turnover, ultrastructure, and gene expression. J. Anim. Sci. 2008, 86, 1132-1144. [CrossRef] [PubMed]

44. Tacoma, R.; Fields, J.; Ebenstein, D.B.; Lam, Y.W.; Greenwood, S.L. Characterization of the bovine milk proteome in early-lactation Holstein and Jersey breeds of dairy cows. J. Proteom. 2016, 130, 200-210. [CrossRef] [PubMed]

45. Vincent, D.; Ezernieks, V.; Elkins, A.; Nguyen, N.; Moate, P.J.; Cocks, B.G.; Rochfort, S. Milk bottom-up proteomics: Method optimisation. Front. Genet. 2016, 6, 360. [CrossRef] [PubMed]

Publisher's Note: MDPI stays neutral with regard to jurisdictional claims in published maps and institutional affiliations.

(C) 2020 by the authors. Licensee MDPI, Basel, Switzerland. This article is an open access article distributed under the terms and conditions of the Creative Commons Attribution (CC BY) license (http://creativecommons.org/licenses/by/4.0/). 